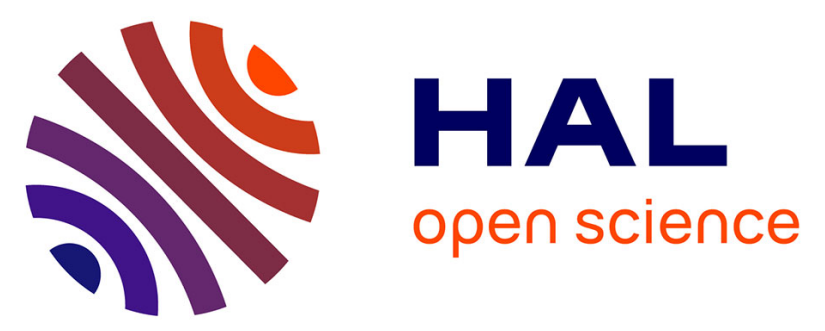

\title{
Absence of oxysterol-like side effects in human monocytic cells treated with phytosterols and oxyphytosterols
}

Anne Vejux, Thomas Montange, Lucy Martine, Amira Zarrouk, Jean-Marc Riedinger, Gérard Lizard

\section{To cite this version:}

Anne Vejux, Thomas Montange, Lucy Martine, Amira Zarrouk, Jean-Marc Riedinger, et al.. Absence of oxysterol-like side effects in human monocytic cells treated with phytosterols and oxyphytosterols. Journal of Agricultural and Food Chemistry, 2012, 60 (16), pp.4060-4066. 10.1021/jf300487r . hal01594323

\section{HAL Id: hal-01594323 \\ https://hal.science/hal-01594323}

Submitted on 26 Sep 2017

HAL is a multi-disciplinary open access archive for the deposit and dissemination of scientific research documents, whether they are published or not. The documents may come from teaching and research institutions in France or abroad, or from public or private research centers.
L'archive ouverte pluridisciplinaire HAL, est destinée au dépôt et à la diffusion de documents scientifiques de niveau recherche, publiés ou non, émanant des établissements d'enseignement et de recherche français ou étrangers, des laboratoires publics ou privés. 


\title{
Absence of Oxysterol-like Side Effects in Human Monocytic Cells Treated with Phytosterols and Oxyphytosterols
}

\author{
Anne Vejux, ${ }^{* \dagger}{ }^{\dagger}$ Thomas Montange, ${ }^{\dagger}$ Lucy Martine, ${ }^{\dagger}$ Amira Zarrouk, ${ }^{\dagger}, \S$ Jean-Marc Riedinger, ${ }^{\#}$ \\ and Gérard Lizard* ${ }^{\dagger}$
${ }^{\dagger}$ Equipe Biochimie du peroxysome, inflammation et métabolisme lipidique (EA7270), Université de Bourgogne - INSERM, Dijon, France
${ }^{\ddagger}$ INRA, UMR Centre des Sciences du Goût et de l'Alimentation (CSGA), Equipe Développement et Dynamique des Préférences et du Comportement Alimentaire, Dijon Cedex, France
${ }^{\S}$ Laboratoire de Biochimie- UR 'Nutrition Humaine et Désordre Métabolique’, Faculté de Médecine, Universite de Monastir, Avenue Avicenne, Monastir, Tunisia
\#Département de Biologie et de Pathologie des Tumeurs, Centre Georges François-Leclerc, 21000 Dijon, France

\begin{abstract}
Oxysterols, found in some commonly consumed foods, can induce a wide range of cytotoxic effects, which have been extensively studied. On the other hand, the side effects of phytosterols and oxyphytosterols are less well-known. Over the past few years, different types of foods have been enriched with phytosterols on the basis of the properties of these compounds that reduce circulating cholesterol levels in certain experimental conditions. It is therefore important to gain better knowledge of the risks and benefits of this type of diet. In this study, conducted in human monocytic U937 cells, the ability of phytosterols (sitosterol, campesterol) and oxyphytosterols (7 $\beta$-hydroxysitosterol, 7-ketositosterol) to induce cell death, polar lipid accumulation, and pro-inflammatory cytokine (MCP-1; IL-8) secretion was determined and compared to that of oxysterols (7ketocholesterol, $7 \beta$-hydroxycholesterol). Phytosterols and oxyphytosterols had no significant effects on the parameters studied; only $7 \beta$-hydroxysitosterol slightly increased cell death, whereas at the concentration used $(20 \mu \mathrm{g} / \mathrm{mL})$, strong cytotoxic effects were observed with the oxysterols. With sitosterol, campesterol, and 7-ketositosterol, IL-8 secretion was decreased, and with campesterol the intracellular polar lipid level was reduced. The data show that phytosterols and oxyphytosterols have no oxysterol-like side effects, and they rather argue in favor of phytosterols' beneficial effects.
\end{abstract}

KEYWORDS: cell death, inflammation, oxysterols, phytosterols, polar lipids, U937 cells

\section{INTRODUCTION}

Cholesterol and its oxidized derivatives (oxysterols) are 27carbon-atom cholesterol oxidation products. ${ }^{1}$ They can be produced endogenously by enzymatic reactions or autoxidation. ${ }^{2}$ In addition, oxysterols may be absorbed from the diet. Oxysterols are found in many commonly consumed foods: milk powder and infant formulas, clarified butter or ghee, red meat (beef, pork), dairy products, eggs and egg products, as well as seafood and seafood products. ${ }^{1,3}$ Some of these oxysterols can induce a wide range of cytotoxic effects: overproduction of reactive oxygen species (ROS) and of pro-inflammatory cytokines, cytoplasmic accumulation of polar lipids (phospholipidosis), and/or activation of cell death (apoptosis associated with a reticulum stress). ${ }^{4,5}$ These events might contribute to the initiation and progression of major age-related diseases: cardiovascular diseases, eye diseases (age-related macular degeneration, cataract, and diabetic retinopathy), neurodegenerative diseases (Alzheimer's disease and dementia of the Alzheimer's type, Parkinson's disease, multiple sclerosis), kidney failure, and osteoporosis. ${ }^{2,6-9}$ The different biological activities of toxic oxysterols, especially for inflammation and cell death, are triggered by metabolic pathways that are interconnected at the mitochondrial level via MEK/ERK1/2 and PI3-K/PDK1/Akt signaling pathways, respectively. ${ }^{2,3,10}$
Phytosterols are structurally related to cholesterol and are mainly C-28 and C-29 carbon steroid alcohols. ${ }^{1}$ The biological activities of phytosterols are less well-known than those of oxysterols. Therefore, a better understanding of the influence of these plant sterols and their oxides on consumer health is needed as the question of benefit versus side effects of these compounds remains highly controversial. ${ }^{11,12}$ Phytosterols, which are not synthesized in mammals, are present in various foodstuffs: oils, spreads, nuts, seeds, and, in lesser quantity, cereals, baked goods, vegetables, and fruits. ${ }^{13}$ Among these phytosterols, $\beta$-sitosterol, stigmasterol, and campesterol are the major phytosterols present in the diet. ${ }^{14}$ Depending on the storage conditions, phytosterols can be oxidized during heat treatments and long storage. ${ }^{15,16}$ These compounds have been identified in the plasma of healthy human subjects, ${ }^{17}$ and their level can be strongly enhanced in some pathological situations: phytosterolemia (characterized by a deficiency in ABCG5 and ABCG8 transporters) or Waldenström's macroglobulinemia. ${ }^{18,19}$ In humans, phytosterol absorption is considerably lower (5\%) than that of dietary cholesterol (50\%). Indeed, the

Received: November 21, 2011

Revised: $\quad$ March 28, 2012

Accepted: April 10, 2012

Published: April 10, 2012 
majority of phytosterols are excreted into the intestinal lumen by sterol transporters such as ABCG5 and ABCG $8,{ }^{1}$ and it has been reported that phytosterols decrease cholesterol absorption and thus reduce the circulating level of cholesterol. ${ }^{20}$ Therefore, phytosterols might have some benefits in preventing cardiovascular diseases, and they could also contribute to preventing cancer and inflammatory diseases. ${ }^{21-23}$ These benefits have led to using phytosterols as nutraceuticals. As the functional food market has grown exponentially in recent years, the understanding of the potential health benefits of phytosterol-enriched foods and nutrients is continually evolving, and there is now some evidence that food supplementation with phytosterols may have detrimental health effects. ${ }^{12}$ Indeed, regular consumption of foods enriched in phytosterols can affect the absorption of carotenoids and fatsoluble vitamins, and elevated levels of phytosterol can also increase cardiovascular risk. ${ }^{12}$

It is therefore necessary to detail the biological activities of phytosterols and their oxidized derivatives (oxyphytosterols) and to compare them with 7 -ketocholesterol and $7 \beta$ hydroxycholesterol, which are potent inducers of cell death, polar lipid accumulation, and cytokine secretion, respectively. ${ }^{2}$

In the present study, the effects of phytosterols (sitosterol, campesterol) and oxyphytosterols, especially sitosterol oxides (7 $\beta$-hydrositosterol, 7-ketositosterol), were evaluated on U937 cells, a well-referenced model, to determine the biological activities of these molecules ${ }^{2,3}$ (Table 1).

Table 1. Composition of the Phytosterol and Oxyphytosterol Solutions Used

$\begin{array}{cccc}\text { sitosterol } & \text { campesterol } & 7 \beta \text {-hydroxysitosterol } & 7 \text {-ketositosterol } \\ \mathbf{9 7 . 6 3 \%} & 12.64 \% & \mathbf{8 8 . 3 5 \% ~ 7 \beta} \text { - } & \mathbf{8 3 . 9 \% ~ 7 - ~} \\ \text { sitosterol } & \text { sitosterol } & \text { hydroxysitosterol } & \text { ketositosterol } \\ 1.69 \% & \mathbf{8 6 . 8 2} \% & 9.6 \% 7 \beta \text { - } & 10.04 \% 7- \\ \text { campesterol } & \text { campesterol } & \text { hydroxycampesterol } & \text { ketocampesterol } \\ 0.68 \% & 0.54 \% & 2 \% \text { impurity } & 6.06 \% \text { stigmasta-3,5- } \\ \text { impurity } & \text { impurity } & & \text { dien-7-one }\end{array}$

\section{MATERIALS AND METHODS}

Chemicals. Propidium iodide, Hoechst 33342, Nile Red (NR), 7ketocholesterol (7KC), $7 \beta$-hydroxycholesterol, and cholesterol were provided by Sigma (L'Isle d'Abeau Chesnes, France). The purity of oxysterols and cholesterol was determined to be $100 \%$ by gaseous phase chromatography coupled with mass spectrometry. Phytosterols and oxyphytosterols were synthesized and provided by Dr. André Grandgirard (INRA, Dijon, France) (Table 1). The planar structures of these different compounds are given in Figure 1. The human monocytic U937 cells used were obtained from the European Collection of Animal Cell Cultures (ECACC, Salisbury, U.K.).

Synthesis and Analysis of Phytosterols and Oxyphytosterols. Phytosterols and oxyphytosterols were prepared as previously described and biochemically characterized using gas-liquid chromatography and gas-liquid chromatography coupled to mass spectrometry. ${ }^{24}$ These compounds were $84-98 \%$ pure.

Cell Culture and Treatments. Human promonocytic U937 cells were grown in RPMI 1640 with GlutaMAX I (Invitrogen, Eragny, France) and antibiotics (100 U/mL penicillin, $100 \mu \mathrm{g} / \mathrm{mL}$ streptomycin; Invitrogen) supplemented with $10 \%(\mathrm{v} / \mathrm{v})$ heatinactivated fetal calf serum (Invitrogen). U937 cells were seeded at 500000 cells $/ \mathrm{mL}$ culture medium and passaged twice a week. U937 cells were chosen because they have been often used to evaluate the biological activities of oxysterols, phytosterols, and oxyphytosterols. ${ }^{8,25}$ For all experiments, a stock solution of sterols was prepared at a concentration of $800 \mu \mathrm{g} / \mathrm{mL}$, as previously described. ${ }^{4}$ In all experiments, phytosterols, oxyphytosterols, cholesterol, and oxysterols were added to the culture medium at the beginning of culture at a final concentration of $20 \mu \mathrm{g} / \mathrm{mL}$, and treatments were carried out for $24 \mathrm{~h}$. We chose to work at $20 \mu \mathrm{g} / \mathrm{mL}$, for $24 \mathrm{~h}$, with phytosterols and oxyphytosterols for the following reasons: with oxysterols used as positive control (7-ketocholesterol, $7 \beta$-hydroxycholesterol) these conditions are optimal to induce cell death and trigger inflammation and phospholipidosis. ${ }^{2,4}$

Flow Cytometric Evaluation of Cell Death with Propidium lodide. Cell viability was determined with propidium iodide (PI) (1 $\mu \mathrm{g} / \mathrm{mL})$, which stains dead cells only. ${ }^{26}$ The red fluorescence was quantified by flow cytometry on 10000 cells with a CyFlow Green flow cytometer (Partec, Münster, Germany) equipped with a green laser emitting at $532 \mathrm{~nm}$. Data were acquired and analyzed using Flowmax software (Partec).

Morphological Characterization of Cell Death by Nuclear Staining with Hoechst 33342. Nuclear morphology was analyzed after nuclear staining with Hoechst $33342(10 \mu \mathrm{g} / \mathrm{mL})$ to distinguish

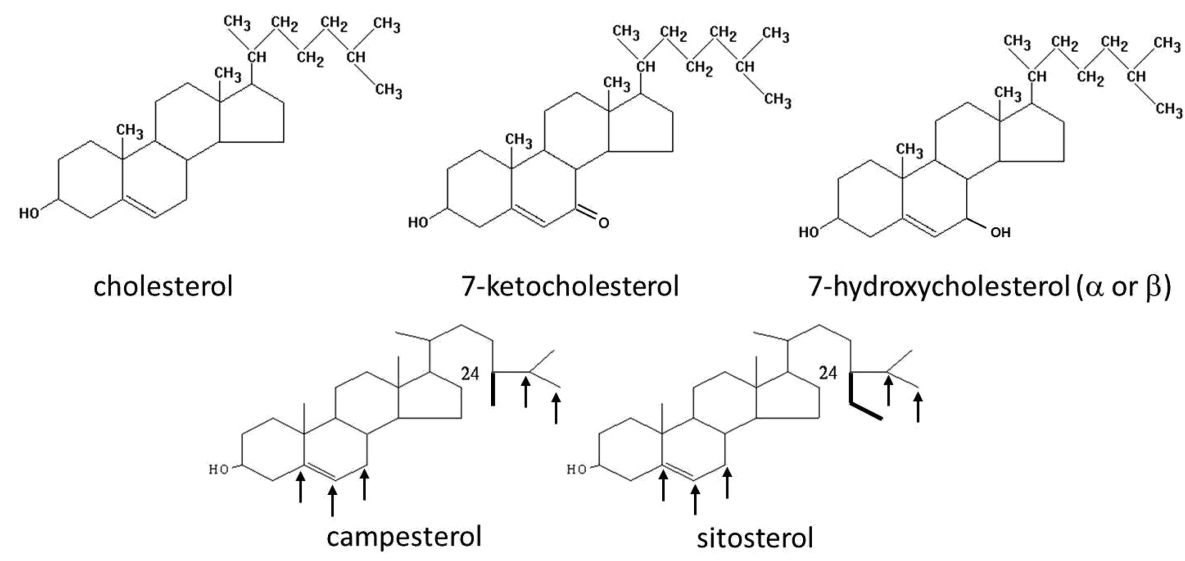

Oxidation sites $\uparrow$

Figure 1. Structures of cholesterol, 7-ketocholesterol, 7-hydroxycholesterol $(\alpha$ or $\beta)$, campesterol, and sitosterol. Campesterol and sitosterol are synthesized via the mevalonate pathway, leading to the production of the precursor squalene. In this synthesis, different sterol methyltransferases are involved and lead to the synthesis of different components: cholesterol-type side chain, campesterol-type side chain, and sitosterol-type side chain. ${ }^{42}$ The methyl group of the C24 position may exist as either of two epimers, $24 \alpha$-methylcholesterol (campesterol) or $24 \beta$-methylcholesterol (dihydrobrassicasterol). (Oxidation sites are indicated by black arrows.) 
between normal cells (cells with round and regular nuclei), necrotic cells (cells with disturbed nuclei of various shapes and sizes), apoptotic cells (cells with condensed and/or fragmented nuclei), and oncotic cells (cells with swollen nuclei). ${ }^{4,26}$ Cell deposits (40 000 cells $/ 100 \mu \mathrm{L}$ of cell preparation) were observed under ultraviolet light by fluorescence microscopy with an Axioskop right microscope (Zeiss, Jena, Germany). For each sample, at least 300 cells were examined with $\times 63$ oil immersion objective.

Flow Cytometric and Confocal Microscopic Evaluation of Polar Lipid Accumulation by Staining with Nile Red. NR is a phenoxazine dye used on living cells to localize and quantify neutral and polar lipids (Sigma). NR stains neutral lipids yellow (570-590 $\mathrm{nm})$ and polar lipids orange-red (590 nm and above) when excited at $488 \mathrm{~nm}^{27}$ When excited at $532 \mathrm{~nm}$, NR can identify polar lipids, which are colored orange-red. ${ }^{28}$ In the present investigation, NR was prepared at $100 \mu \mathrm{g} / \mathrm{mL}$ in DMSO and used as previously described at $0.1 \mu \mathrm{g} / \mathrm{mL}$ final concentration. ${ }^{28}$ Flow cytometric analyses were performed on a Galaxy flow cytometer. For each sample, 10000 cells were acquired and analyzed with the Flowmax software. For confocal microscopical analyses, $30 \mu \mathrm{L}$ of a cellular suspension stained with $\mathrm{NR}$ and adjusted at $10^{6}$ cells $/ \mathrm{mL}$ was applied to glass slides, air-dried, mounted in a fluorescent mounting medium (Dako, Copenhagen, Denmark), coverslipped, and stored in the dark at $4{ }^{\circ} \mathrm{C}$ before examination.

Measurement of Interleukin-8 and Monocyte Chemotactic Protein-1 Secretion by ELISA. To measure interleukin-8 (IL-8) and monocyte chemoattractant protein-1 (MCP-1) secretion by ELISA, U937 cells were incubated for $24 \mathrm{~h}$ with phytosterols, oxyphytosterols, cholesterol, and oxysterols. At the end of the incubation time, the culture medium was collected by centrifugation and stored at $-80{ }^{\circ} \mathrm{C}$. Samples were defrosted just before ELISA was carried out according to the manufacturer's procedure (Bender MedSystems, Vienna, Austria). ${ }^{29}$ Human plasma containing or not IL-8 and MCP-1 was used as positive and negative control, respectively.

Statistical Analysis. Statistical analyses were performed using WinSTAT software (Microsoft). The Mann-Whitney $U$ test was used to compare the different groups, and data were considered to be statistically different at a $P$ value of $\leq 0.05$.

\section{RESULTS AND DISCUSSION}

The effects of phytosterols (sitosterol, campesterol) and oxyphytosterols (7 $\beta$-hydrositosterol, 7-ketositosterol) $(20 \mu \mathrm{g} /$ $\mathrm{mL})$ were measured and compared to those induced by 7 ketocholesterol, $7 \beta$-hydroxycholesterol, and cholesterol used at a similar concentration (Table 1). At this concentration and in U937 cells, 7-ketocholesterol induced cell death and intracellular accumulation of polar lipids, ${ }^{28}$ whereas $7 \beta$-hydroxycholesterol triggered cell death and IL-8 secretion. ${ }^{29}$ In the phytosterols and oxyphytosterols solutions used, as sitosterol, campesterol, $7 \beta$-hydrositosterol, and 7-ketositosterol represent 84 and 98\% (Table 1), we can consider that the major compound is responsible for the biological effects.

In the present experimental conditions after $24 \mathrm{~h}$ of incubation with phytosterols (sitosterol or campesterol) or oxyphytosterols ( $7 \beta$-hydroxysitosterol or 7 -ketositosterol), the impact of these compounds on cell death was determined compared to those of 7-ketocholesterol, $7 \beta$-hydroxycholesterol, and cholesterol after staining with PI. Interestingly, among the compounds tested, no induction of cell death was observed with sitosterol, campesterol, 7-ketositosterol, or cholesterol, and a very slight but significant induction of cell death was found with $7 \beta$-hydroxysitosterol, whereas 7 -ketocholesterol and $7 \beta$ hydroxycholesterol were able to strongly increase cellular permeability to PI (Figure 2). As apoptotic cells are not permeable to $\mathrm{PI}{ }^{26}$ a morphological examination of the cell nuclei distinguishing between viable, apoptotic, necrotic, and oncotic cells was carried out after staining with Hoechst

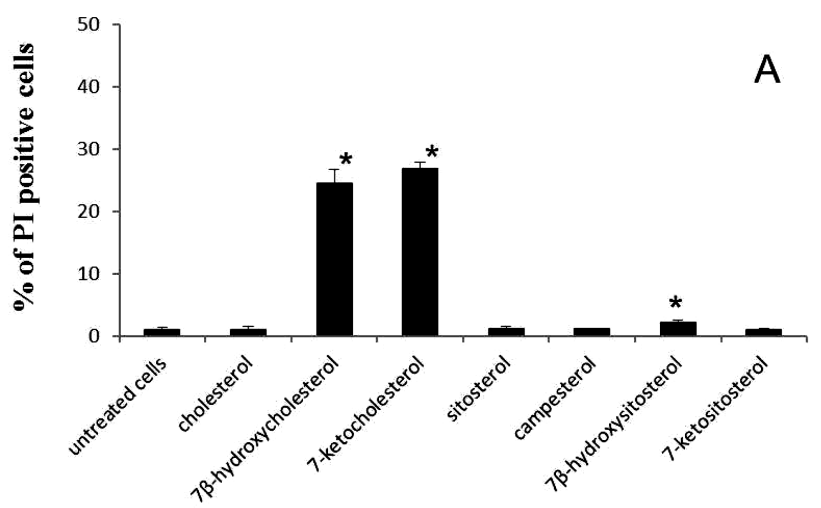

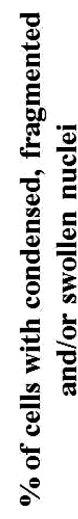

B

Figure 2. Effects of different sterols (cholesterol, $7 \beta$-hydroxycholesterol, 7-ketocholesterol, sitosterol, campesterol, $7 \beta$-hydroxysitosterol, and 7-ketositosterol) $(20 \mu \mathrm{g} / \mathrm{mL}, 24 \mathrm{~h})$ on cell viability of U937 cells: (A) evaluation of the percentage of dead cells after staining with propidium iodide (PI); (B) characterization of cell death after staining with Hoechst 33342. Data represent three individual experiments (mean \pm $\mathrm{SE})$. Mann-Whitney test: comparison of treated versus untreated cells. $*, P \leq 0.05$.

$33342 .^{26}$ With phytosterols, oxyphytosterols, and cholesterol, mainly cells with nuclei with regular sizes and shapes, characteristic of living cells, were observed (Figure 2), whereas in agreement with previous data, 7-ketocholesterol and $7 \beta$ hydroxycholesterol induced an apoptotic mode of cell death associated with the presence of oncotic cells. ${ }^{8}$ Thus, no or minor incidence on cell viability was observed under treatment with phytosterols (sitosterol or campesterol) and oxyphytosterols (7 $\beta$-hydrositosterol or 7-ketositosterol). In agreement with our observations, Maguire et al. reported in U937 cells that $\beta$ sitosterol (30 and $60 \mu \mathrm{M}), \alpha$-epoxysitosterol $(60 \mu \mathrm{M})$, and $\beta$ sitosterol oxides $(30 \mu \mathrm{M})$ were unable to induce cell death. ${ }^{30}$ With $\beta$-sitosterol oxides, 60 and $120 \mu \mathrm{M}$ concentrations were required to reduce cell viability to 35 and $66 \%$, respectively, and to induce an apoptotic mode of cell death. ${ }^{30}$ With 7ketositosterol and $7 \beta$-hydroxysitosterol, concentrations as high as 60 and $120 \mu \mathrm{M}$ were also required to induce high percentages of dead cells in U937, Caco-2, and HepG2 cells. ${ }^{31}$ O'Callaghan et al. also demonstrated that stigmasterol oxides were mainly toxic in the highest concentrations tested (60-120 $\mu \mathrm{M})$ and were able to induce apoptosis involving glutathione depletion, caspase- 3 activation, and Bcl-2 down-regulation. ${ }^{25}$ In HepG2 cells, Koschutnig et al. demonstrated that 7ketositosterol was more cytotoxic than $7 \alpha$-hydroxysitosterol, whereas $7 \beta$-hydroxysitosterol had no effect. ${ }^{32}$ Moreover, when the cytotoxicity of cholesterol, of a mixture of $\beta$-sitosterol and 
A

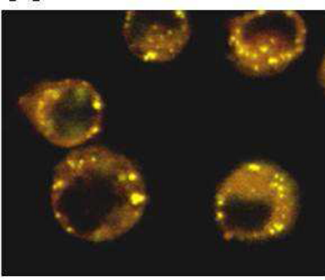

Untreated cells

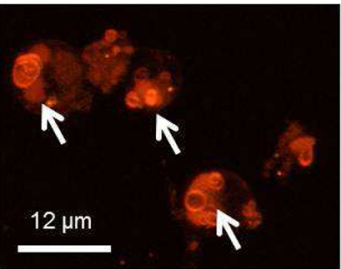

7-ketocholesterol
B

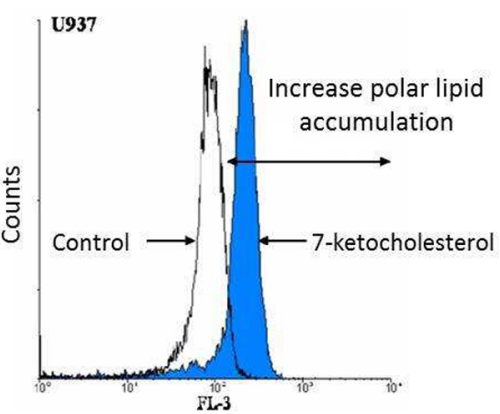

C

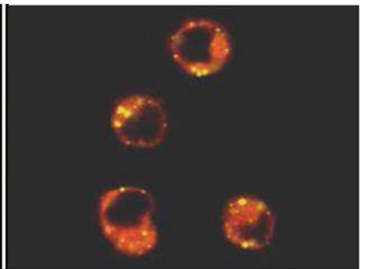

Campesterol

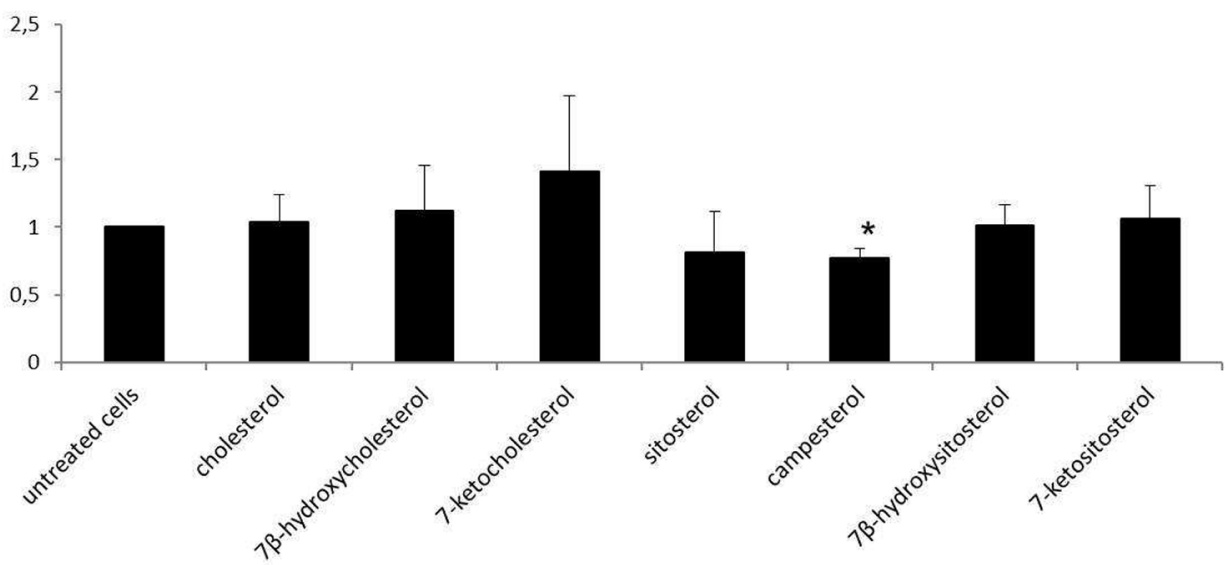

Figure 3. Quantification of polar lipids with Nile Red. U937 cells were treated with cholesterol, $7 \beta$-hydroxycholesterol, 7-ketocholesterol, sitosterol, campesterol, $7 \beta$-hydroxysitosterol, or 7-ketositosterol $(20 \mu \mathrm{g} / \mathrm{mL}, 24 \mathrm{~h})$ and then stained with NR. Under a blue light, NR gives a yellow fluorescence with neutral lipids and an orange-red fluorescence with polar lipids. (A) Confocal microscopy of NR stained cells: (left) untreated cells (some yellow spots can be observed); cells with similar aspects were visualized under treatments with phytosterols and oxyphytosterols (data not shown); (right) 7-ketocholesterol-treated cells (large orange-red cytoplasmic structures (white arrows), suggesting phospholipidosis was detected; ${ }^{2}$ cells with similar aspects were observed with $7 \beta$-hydroxycholesterol (data not shown). (B, C) Flow cytometric analysis of polar lipid content after staining with NR. Similar data were obtained when cholesterol, sitosterol, campesterol, $7 \beta$-hydroxysitosterol, and 7-ketositosterol were used at 20 $\mu \mathrm{g} / \mathrm{mL}$ for $24 \mathrm{~h}$. Data represent three individual experiments (mean $\pm \mathrm{SE}$ ). Mann-Whitney test: comparison of treated versus untreated-cells. $*, P$ $\leq 0.05$.

campesterol (50 and 40\%, respectively), and of their oxides $(200 \mu \mathrm{g} / \mathrm{mL}$ for up to $120 \mathrm{~h})$ was examined in a culturedderived macrophage cell line from $\mathrm{C} 57 \mathrm{BL} / 6$ mice, it was demonstrated that these phytosterols and oxyphytosterols may cause cellular damages similar to oxysterols, although less severe. ${ }^{33}$ Whereas the toxicity of phytosterols and oxyphytosterols must be considered with caution, ${ }^{34-36}$ results from a previous study and those obtained in the present investigation show that phytosterols and oxyphytosterols are less active than oxysterols and that elevated concentrations of phytosterols or oxyphytosterols, 30-60 times higher than those observed in the plasma of healthy subjects receiving a conventional diet, ${ }^{19}$ are required to induce cell death.

Next, we studied the effects of phytosterols, oxyphytosterols, oxysterols, and cholesterol on cellular lipid content. To this end, NR staining was used to visualize both polar and neutral lipids because this dye stains polar lipids orange-red (590-620 $\mathrm{nm}$ ) and neutral lipids yellow $(570-590 \mathrm{~nm})$ when excited at $488 \mathrm{~nm}^{28}$ (Figure 3). Until now, some studies have focused on the effects of phytosterols on circulating cholesterol, ${ }^{37,38}$ but no investigation has been conducted to determine the effect of phytosterols on polar lipids. With sitosterol, campesterol, $7 \beta$ hydroxysitosterol, and 7-ketositosterol as well as under treatment with cholesterol (used at $20 \mu \mathrm{g} / \mathrm{mL}$ ), the staining pattern obtained by microscopy with $\mathrm{NR}$ was similar to untreated cells (Figure 3A). However, under treatment with 7ketocholesterol and $7 \beta$-hydroxycholesterol used at the same concentration, only a few yellow spots were observed, whereas large orange-red cytoplasmic structures, evoking phospholipidosis, were detected ${ }^{2,28}$ (Figure 3A). This increase of red cytoplasmic structures was confirmed by flow cytometry (Figure 3B). The ratios [orange-red mean fluorescence intensity of treated cells/orange-red mean fluorescence intensity of untreated cells] were also determined by flow cytometry for the different compounds used (Figure 3C): with $7 \beta$-hydroxysitosterol and 7-ketositosterol, this ratio was similar to that in untreated cells; with sitosterol, although not statistically significant, this ratio was decreased; with campesterol, we observed a significant decrease of this ratio, suggesting a reduction of polar lipids. In agreement with previous data, with 7 -ketocholesterol and $7 \beta$-hydroxycholesterol a marked increase of the ratio was found. ${ }^{28}$ Thus, in contrast to 7 -ketocholesterol and $7 \beta$-hydroxycholesterol, our data establish that sitosterol, campesterol, $7 \beta$-hydroxysitosterol, and 7-ketositosterol are unable to induce phospholipidosis. Moreover, as it has been proposed that phospholipids might 
favor stress response in the cells of the vascular wall, the ability of campesterol and sitosterol to reduce polar lipids may prevent vascular damage. . $^{390}$

Because inflammation plays crucial roles in the initiation and development of some diseases, and as oxysterols are known to activate the secretion of pro-inflammatory cytokines, ${ }^{2}$ we also studied the capacity of phytosterols and oxyphytosterols to induce pro-inflammatory cytokine secretion (IL-8, MCP-1) on U937 cells. When compared to $7 \beta$-hydroxycholesterol, which is a strong inducer of IL-8 secretion in U937 cells, ${ }^{4,29}$ treatment with sitosterol, campesterol, and 7-ketositosterol induced either a slight nonsignificant or significant decrease in IL-8 secretion (Table 2; $P$ values for sitosterol, campesterol, and 7-

Table 2. IL-8 and MCP-1 Secretion in Untreated U937 Cells and in U937 Cells Treated with Cholesterol, $7 \boldsymbol{\beta}$ Hydroxycholesterol, 7-Ketocholesterol, Sitosterol, Campesterol, $7 \boldsymbol{\beta}$-Hydroxysitosterol, or 7 -Ketositosterol ${ }^{a}$

\begin{tabular}{|lcc|}
\hline \multicolumn{1}{c}{ treatment } & MCP-1 $(\mathrm{pg} / \mathrm{mL})$ & $\mathrm{IL}-8(\mathrm{pg} / \mathrm{mL})$ \\
\hline control & $1100.8 \pm 122$ & $87.7 \pm 11$ \\
cholesterol & $1065 \pm 107$ & $82.7 \pm 1$ \\
7 $\beta$-hydroxycholesterol & $\mathbf{3 5 1 . 2} \pm \mathbf{2 3 ^ { * }}$ & $\mathbf{4 9 1 . 8} \pm \mathbf{1}^{*}$ \\
7-ketocholesterol & $\mathbf{6 0 7 . 4} \pm \mathbf{1 9 *}$ & $91.9 \pm 1$ \\
sitosterol & $1068.3 \pm 92$ & $76.9 \pm 1$ \\
campesterol & $1099.9 \pm 6$ & $77.7 \pm 1$ \\
7 $\beta$-hydroxysitosterol & $945.3 \pm 193$ & $95.3 \pm 1$ \\
7-ketositosterol & $1091.2 \pm 80$ & $\mathbf{7 4 . 4} \pm \mathbf{1}^{*}$
\end{tabular}

${ }^{a}$ Data represent three individual experiments (mean $\pm \mathrm{SE}$ ). MannWhitney test: comparison of treated versus untreated cells. $*, P \leq 0.05$. U937 (500 000 cells $/ \mathrm{mL}$ ) treatments: cholesterol, oxysterols, or phytosterols $(20 \mu \mathrm{g} / \mathrm{mL} ; 24 \mathrm{~h})$.

ketositosterol $=0.121,0.376$, and 0.049 , respectively). IL-8 concentration in the culture medium of cholesterol-, 7ketocholesterol-, and $7 \beta$-hydroxysitosterol-treated cells was in the same range as in the culture medium of untreated cells (Table 2). When the effects of these different compounds were evaluated on the secretion of MCP-1, no effects were observed with cholesterol, sitosterol, campesterol, $7 \beta$-hydroxysitosterol, and 7-ketositosterol, whereas marked decreases were observed with $7 \beta$-hydroxycholesterol and 7-ketocholesterol. As these oxysterols are potent inducers of cell death, it can be supposed that this inhibition of MCP-1 secretion is related to cell death induction. In agreement with our data, potential antiinflammatory activities of phytosterols and oxyphytosterols have been reported. In previous studies, the effect of phytosterols and oxyphytosterols on cytokine secretion was determined on a mouse model of 12-O-tetradecanoylphorbol13-acetate (TPA)-induced inflammation. In this model, the oxygenated stigmastane-type sterols stigmastane- $3 \beta, 6 \alpha$-diol, stigmastane- $3 \beta, 6 \beta$-diol, and their diacyl derivatives were able to inhibit TPA-induced inflammation in mice. ${ }^{41}$ More recently, Calpe-Berdiel et al. demonstrated that phytosterol intake was able to modulate immune response. ${ }^{42}$ A study conducted by Kurano et al. describes lower levels of pro-inflammatory cytokine secretion (TNF- $\alpha$, IL-6) in macrophages treated with phytosterols (sitosterol, campesterol). ${ }^{43}$ Using experimental autoimmune encephalomyelitis (EAE), an animal model for multiple sclerosis (MS), Valerio et al. demonstrated reduced inflammatory activities of immune cells (increased IL-10 level and increased CCL2, TNF- $\alpha$, IFN- $\gamma$, and IL-6 levels) in the central nervous system of the mice receiving a daily phytosterol emulsion ( $\beta$-sitosterol (60\%), campesterol (25\%), and stigmasterol $(15 \%))$ via gavage. ${ }^{23}$ Altogether, our results support that certain phytosterols and oxyphytosterols can modulate immune response.

In conclusion, in U937 cells, phytosterols (sitosterol, campesterol) and oxyphytosterols (7-ketositosterol, $7 \beta$-hydroxysitosterol) do not induce cell death, do not favor polar lipid accumulation, and do not stimulate IL-8 secretion (a slight decrease was even observed), which are major oxysterol side effects. $^{2,3}$ They also do not modulate MCP-1 secretion. Although the in vivo toxicity of phytosterols (sitosterol, campesterol) and oxyphytosterols (7-ketositosterol, $7 \beta$-hydroxysitosterol) studied is not excluded (under conditions of regular consumption of processed food enriched with these compounds ${ }^{12}$ ), the present investigation shows the absence of toxicity of these compounds at a concentration $(20 \mu \mathrm{g} / \mathrm{mL})$ known to induce strong cytotoxic effects with 7-ketocholesterol and $7 \beta$-hydroxycholesterol. This study suggests that it would be important to reconsider the analysis of cholesterol derivatives (oxysterols) and cholesterol structurally related products (such as phytosterols) in foods. Indeed, as 7-ketocholesterol and $7 \beta$ hydroxycholesterol, ${ }^{9,44,45}$ can be present in large quantities in the diet, it is important to take care of not only phytosterol and oxyphytosterol content but also oxysterol content. This could be significant in terms of public health given the involvement of oxysterols in numerous widespread age-related diseases such as cardiovascular and neurodegenerative diseases.

\section{AUTHOR INFORMATION}

\section{Corresponding Author}

*Postal address: (G.L. or A.V.) Université de Bourgogne/ Equipe BIO-peroxIL (EA7270), Faculté des Sciences Gabriel, 6 Bd Gabriel, 21000 Dijon, France. Phone: +33 380396256. Fax: +33 3803962 50. E-mail: (G.L.) Gerard.Lizard@ubourgogne.fr or (A.V.) Anne.Vejux@u-bourgogne.fr.

\section{Funding}

This work was supported by INSERM and the Universite de Bourgogne.

\section{Notes}

The authors declare no competing financial interest.

\section{ACKNOWLEDGMENTS}

We are indebted to Linda Northrup for reviewing the English version of the manuscript.

\section{REFERENCES}

(1) Otaegui-Arrazola, A.; Menendez-Carreno, M.; Ansorena, D.; Astiasaran, I. Oxysterols: a world to explore. Food Chem. Toxicol. 2010, 48, 3289-3303.

(2) Vejux, A.; Lizard, L. Cytotoxic effects of oxysterols associated with human diseases: induction of cell death (apoptosis and/or oncosis), oxidative and inflammatory activities, and phospholipidosis. Mol. Aspects Med. 2009, 30, 153-170.

(3) Lordan, S.; Mackrill, J. J.; O’Brien, N. M. Oxysterols and mechanisms of apoptotic signaling: implications in the pathology of degenerative diseases. J. Nutr. Biochem. 2009, 20, 321-336.

(4) Lemaire-Ewing, S.; Prunet, C.; Montange, T.; Vejux, A.; Berthier, A.; Bessède, G.; Pais de Barros, J. P.; Laubriet, A.; Gambert, P.; Lizard, G.; Néel, D. Comparison of the cytotoxic, pro-oxydant and proinflammatory characteristics of different oxysterols. Cell Biol. Toxicol. 2005, 21, 97-114.

(5) Pedruzzi, E.; Guichard, C.; Ollivier, V.; Driss, F.; Fay, M.; Prunet, C.; Marie, J. C.; Pouzet, C.; Samadi, M.; Elbim, C.; O’dowd, Y.; Bens, M.; Vandewalle, A.; Gougerot-Pocidalo, M. A.; Lizard, G.; Ogier- 
Denis, E. NAD $(\mathrm{P}) \mathrm{H}$ oxidase Nox-4 mediates 7-ketocholesterolinduced endoplasmic reticulum stress and apoptosis in human aortic smooth muscle cells. Mol. Cell. Biol. 2004, 24, 10703-10717.

(6) Curcio, C. A.; Millican, C. L.; Bailey, T.; Kruth, H. S. Accumulation of cholesterol with age in human Bruch's membrane. Invest. Ophthalmol. Vis. Sci. 2001, 4, 265-274.

(7) Sottero, B.; Gamba, P.; Gargiulo, S.; Leonarduzzi, G.; Poli, G. Cholesterol oxidation products and disease: an emerging topic of interest in medicinal chemistry. Curr. Med. Chem. 2009, 16, 685-705.

(8) Vejux, A.; Malvitte, L.; Lizard, G. Side effects of oxysterols: cytotoxicity, oxidation, inflammation, and phospholipidosis. Braz. J. Med. Biol. Res. 2008, 41, 545-556.

(9) Vejux, A.; Samadi, M.; Lizard, G. Contribution of cholesterol and oxysterols in the physiopathology of cataract: implication for the development of pharmacological treatments. J. Ophtalmol. 2011, 471947.

(10) Ragot, K.; Delmas, D.; Athias, A.; Nury, T.; Baarine, M.; Lizard, G. $\alpha$-Tocopherol impairs 7-ketocholesterol-induced caspase-3-dependent apoptosis involving GSK-3 activation and Mcl-1 degradation on $158 \mathrm{~N}$ murine oligodendrocytes. Chem. Phys. Lipids 2011, 164, 469478.

(11) Williamson, A. Functional foods: what are the benefits? $\mathrm{Br}$. J. Community Nurs. 2009, 14, 230-236.

(12) Weingärtner, O.; Böhm, M.; Laufs, U. Controversial role of plant sterol esters in the management of hypercholesterolaemia. Eur. Heart J. 2009, 30, 404-409.

(13) Conchillo, A.; Cercaci, L.; Ansorena, D.; Rodriguez-Estrada, M. T.; Lercker, G.; Astiasarán, I. Levels of phytosterol oxides in enriched and nonenriched spreads: application of a thin-layer chromatographygas chromatography methodology. J. Agric. Food Chem. 2005, 53, $7844-7850$

(14) Ostlund, E., Jr. Phytosterols inhuman nutrition. Annu. Rev. Nutr. 2002, 22, 533-549.

(15) Daly, G. G.; Finocchiaro, E. T.; Richardson, T. Characterization of some oxidation products of $\beta$-sitosterol. J. Agric. Food Chem. 1983, $31,46-50$.

(16) Dutta, P. C.; Savage, G. P. Formation and content of phytosterol oxidation product in foods. In Cholesterol and Phytosterol Oxidation Products: Analysis, Occurrence, and Biological Effects; Guardiola, F., Dutta, P. C., Codony, R., Savage, G. P., Eds.; AOAC Press: Champaign, IL, USA, 2002; pp 319-334.

(17) Grandgirard, A.; Martine, L.; Demaison, L.; Cordelet, C.; Joffre, C.; Berdeaux, O.; Semon, E. Oxyphytosterols are present in plasma of healthy human subjects. Br. J. Nutr. 2004, 91, 101-106.

(18) Brooks, C. J.; Cole, W. J.; Lawrie, T. D.; MacLachlan, J.; Borthwick, J. H.; Barrett, G. M. Selective reactions in the analytical characterisation of steroids by gas chromatography-mass spectrometry. J. Steroid Biochem. 1983, 19, 189-201.

(19) Plat, J.; Brzezinka, H.; Lütjohann, D.; Mensink, R. P.; von Bergmann, K. Oxidized plant sterols in human serum and lipid infusions as measured by combined gas-liquid chromatography-mass spectrometry. J. Lipid Res. 2001, 42, 2030-2038.

(20) Gupta, A.; Guyomard, V.; Zaman, M. J.; Rehman, H. U.; Myint, P. K. Systematic review on evidence of the effectiveness of cholesterollowering drugs. Adv. Ther. 2010, 27, 348-364.

(21) Jones, P. J.; AbuMweis, S. S. Phytosterols as functional food ingredients: linkages to cardiovascular disease and cancer. Curr. Opin. Clin. Nutr. Metab. Care. 2009, 12, 147-151.

(22) Bradford, P. G.; Awad, A. B. Modulation of signal transduction in cancer cells by phytosterols. Biofactors 2010, 36, 241-247.

(23) Valerio, M.; Liu, H. B.; Heffner, R.; Zivadinov, R.; Ramanathan, M.; Weinstock-Guttman, B.; Awad, A. B. Phytosterols ameliorate clinical manifestations and inflammation in experimental autoimmune encephalomyelitis. Inflamm. Res. 2011, 60, 457-465.

(24) Grandgirard, A.; Martine, L.; Joffre, C.; Juaneda, P.; Berdeaux, $\mathrm{O}$. Gas chromatographic separation and mass spectrometric identification of mixtures of oxyphytosterol and oxycholesterol derivatives - application to a phytosterol-enriched food. J. Chromatogr., A 2004, 1040, 239-250.
(25) O’Callaghan, Y. C.; Foley, D. A.; O’Connell, N. M.; McCarthy, F. O.; Maguire, A. R; O’Brien, N. M. Cytotoxic and apoptotic effects of the oxidized derivatives of stigmasterol in the U937 human monocytic cell line. J. Agric. Food Chem. 2010, 58, 10793-10798.

(26) Lizard, G.; Fournel, S.; Genestier, L.; Dhedin, N.; Chaput, C.; Flacher, M.; Mutin, M.; Panaye, G.; Revillard, J. P. Kinetics of plasma membrane and mitochondrial alterations in cells undergoing apoptosis. Cytometry 1995, 21, 275-283.

(27) Klinkner, A. M.; Bugelski, P. J.; Waites, R.; Louden, C.; Hart, T. K.; Kerns, W. D. A novel technique for mapping the lipid composition of atherosclerotic fatty streaks by en face fluorescence microscopy. J. Histochem. Cytochem. 1997, 45, 743-753.

(28) Vejux, A.; Kahn, E.; Dumas, D.; Bessède, G.; Ménétrier, F.; Athias, A.; Riedinger, J. M.; Frouin, F.; Stoltz, J. F.; Ogier-Denis, E.; Todd-Pokropek, A.; Lizard, G. 7-ketocholesterol favors lipid accumulation and colocalizes with Nile Red positive cytoplasmic structures formed during 7-ketocholesterol-induced apoptosis: analysis by flow cytometry, FRET biphoton spectral imaging microscopy, and subcellular fractionation. Cytometry A 2005, 64, 87-100.

(29) Prunet, C.; Montange, T.; Vejux, A.; Laubriet, A.; Rohmer, J. F.; Riedinger, J. M.; Athias, A.; Lemaire-Ewing, S.; Néel, D.; Petit, J. M.; Steinmetz, E.; Brenot, R.; Gambert, P.; Lizard, G. Multiplexed flow cytometric analyses of pro- and anti-inflammatory cytokines in the culture media of oxysterol-treated human monocytic cells and in the sera of atherosclerotic patients. Cytometry A 2006, 69, 359-373.

(30) Maguire, L.; Konoplyannikov, M.; Ford, A.; Maguire, A. R.; O'Brien, N. M. Comparison of the cytotoxic effects of $\beta$-sitosterol oxides and a cholesterol oxide, $7 \beta$-hydroxycholesterol, in cultured mammalian cells. Br. J. Nutr. 2003, 90, 767-775.

(31) Ryan, E.; Chopra, J.; McCarthy, F.; Maguire, A. R.; O’Brien, N. M. Qualitative and quantitative comparison of the cytotoxic and apoptotic potential of phytosterol oxidation products with their corresponding cholesterol oxidation products. Br. J. Nutr. 2005, 94, 443-451.

(32) Koschutnig, K.; Heikkinen, S.; Kemmo, S.; Lampi, A. M.; Piironen, V.; Wagner, K. H. Cytotoxic and apoptotic effects of single and mixed oxides of $\beta$-sitosterol on HepG2-cells. Toxicol. In Vitro 2009, 23, 755-762.

(33) Adcox, C.; Boyd, L.; Oehrl, L.; Allen, J.; Fenner, G. Comparative effects of phytosterol oxides and cholesterol oxides in cultured macrophage-derived cell lines. J. Agric. Food Chem. 2001, 49, 20902095.

(34) Lizard, G. Phytosterols: to be or not to be toxic; that is the question. Br. J. Nutr. 2008, 100, 1150-1151.

(35) Rubis, B.; Paszel, A.; Kaczmarek, M.; Rudzinska, M..; Jelen, H.; Rybczynska, M. Beneficial or harmful influence of phytosterols on human cells? Br. J. Nutr. 2008, 100, 1183-1191.

(36) Danesi, F.; Ferioli, F.; Caboni, M. F.; Boschetti, E.; Di Nunzio, M.; Verardo, V.; Valli, V.; Astolfi, A.; Pessio,n, A.; Bordoni, A. Phytosterol supplementation reduces metabolic activity and slows cell growth in cultured rat cardiomyocytes. Br. J. Nutr. 2011, 106, 540548.

(37) Cohn, J. S.; Kamili, A.; Wat, E.; Chung, R. W.; Tandy, S. Reduction in intestinal cholesterol absorption by various food components: mechanisms and implications. Atheroscler. Suppl. 2010, $11,45-48$.

(38) Sanclemente, T.; Marques-Lopes, I.; Fajó-Pascual, M.; Cofán, M.; Jarauta, E.; Ros, E.; Puzo, J.; García-Otín, A. L. Naturally-occurring phytosterols in the usual diet influence cholesterol metabolism in healthy subjects. Nutr. Metab. Cardiovasc. Dis. 2011, in press (http:// dx.doi.org/10.1016/j.numecd.2011.01.010).

(39) Zhang, W.; Salomon, R. G. Oxidized phospholipids, isolevuglandins, and atherosclerosis. Mol. Nutr. Food Res. 2005, 11, $1050-1062$.

(40) Leitinger, N. Oxidized phospholipids as modulators of inflammation in atherosclerosis. Curr. Opin. Lipidol. 2003, 14, 421430.

(41) Kimura, Y.; Yasukawa, K.; Takido, M.; Akihisa, T.; Tamura, T. Inhibitory effect of some oxygenated stigmastane-type sterols on 12-O- 
tetradecanoylphorbol-13-acetate-induced inflammation in mice. Biol. Pharm. Bull. 1995, 18, 1617-1619.

(42) Calpe-Berdiel, L.; Escolà-Gil, J. C.; Benítez, S.; Bancells, C.; González-Sastre, F.; Palomer, X.; Blanco-Vaca, F. Dietary phytosterols modulate T-helper immune response but do not induce apparent antiinflammatory effects in a mouse model of acute, aseptic inflammation. Life Sci. 2007, 80, 1951-1956.

(43) Kurano, M.; Iso-O, N.; Hara, M.; Noiri, E.; Koike, K.; Kadowaki, T.; Tsukamoto, K. Plant sterols increased IL- 6 and TNF- $\alpha$ secretion from macrophages, but to a lesser extent than cholesterol. J. Atheroscler. Thromb. 2011, 18, 373-383.

(44) Schroepfer, G. J., Jr. Oxysterols: modulators of cholesterol metabolism and other processes. Physiol. Rev. 2000, 80, 361-554.

(45) Schaller, $\mathrm{H}$. The role of sterols in plant growth and development. Prog. Lipid Res. 2003, 42, 163-175. 